\title{
Penggunaan Metode Proyek untuk Meningkatkan Prestasi Belajar Materi Tumbuhan Hijau pada Siswa Kelas V di SDN 2 Ngepeh Kecamatan Tugu Kabupaten Trenggalek
}

\author{
Endang Suprapti \\ Sekolah Dasar Negeri 2 Ngepeh KecamatanTugu Kab. Trenggalek \\ Emai : endangsuprapti@gmail.com
}

\begin{abstract}
Abstrak: Penelitian ini dilakukan untuk mengetahui hasil dari penerapan metode proyek untuk meningkatkan hasil belajar siswa kelas $\mathrm{V}$ pada materi tumbuhan hijau di SDN Ngepeh Kecamatan Tugu Kabupaten Trenggalek. Pada kenyataannya keterlinatan siswa dalam pembelajaran tumbuhan hijau masih sangat kurang sehingga mempengaruhi pemahaman siswa. Terdapat $50 \%$ siswa dari 28 siswa yang memperoleh nilai di bawah KKM. Dengan metode proyek anak mampu merancang dan melakukan percobaan membuktikan secara langsung. Penelitian ini termasuk dalam penelitian tindakan kelas dengan dua siklus. Teknik analisis data menggunakan observasi dan tes. Hasil dari penelitian menunjukkan bahwa

\begin{tabular}{l}
\hline Tersedia Online di \\
\hline http://journal.unublitar.ac.id/pendidika \\
\hline n/index.php/Riset_Konseptual \\
\hline Sejarah Artikel \\
\hline Diterima pada : 02-04-2020 \\
Disetuji pada : 29-04-2020 \\
Dipublikasikan pada : 30-04-2020
\end{tabular}

Kata Kunci:

metode pembelajaran proyek, aktivitas belajar, materi tumbuhan hijau

DOI:

http://doi.org/10.28926/riset_konseptual.v4i2. 213 adanya peningkatan nilai ketuntasan belajar pada masing-masing siklus, yaitu yang semula siklus I total ketuntasan belajar sebesar (57\%), sedangkan pada siklus II menjadi (85\%). Penerapan model pembelajaran ini membuat siswa lebih termotivasi dan bersemangat dalam mengikuti pembelajaran sehingga diperoleh pengalaman dan hasil belajar yang memuaskan.
\end{abstract}

\section{PENDAHULUAN}

Seiring berkembangnya ilmu pengetahuan dan teknologi, pemerintah melakukan berbagai upaya untuk meningkatan kualitas sumber daya manusia di segala bidang, khusunya bidang pendidikan untuk mencetak generasi penerus bangsa. Peningkatan mutu pendidikan tersebut bisa dilaksanakan dengan menyediakan sarana dan prasarana yang memadai, memanfaatkan media pembelajaran secara maksimal, dan meningkatkan kualitas guru dalam mengelola pembelajaran.

Guru merupakan faktor penting dan berpengaruh untuk menciptakan suasana belajar yang baik dalam mendukung keberhasilan dalam kegiatan pembelajaran di kelas. Keberhasilan proses pembelajaran didukung oleh motivasi siswa dalam belajar dan pengelolaan kelas yang baik. Oleh sebab itu, guru diharuskan memiliki kemampuan yang memadai untuk menjalankan tugas profesionalnya. Diantara kemampuan tersebut adalah kemampuan dalam pemilihan metode pembelajaran seperti halya pada mata pelajaran IPA.

Salah satu cara yang dapat digunakan pada pembelajaran IPA adalah dengan menerapkannya metode proyek. Metode proyek dapat meningkatkan kreatifitas dan motivasi siswa karena metode ini dapat memberikan pengalaman pada siswa untuk belajar secara mandiri sehingga melatih siswa dalam menyelesaikan masalah. Hal ini sesuai dengan pendapat Thomas, dkk (dalam Wena, 2011) yang menyatakan siswa dituntut untuk memecahkan masalah, merancang, melakukan kegiatan investigasi, membuat keputusan, serta memberikan kesempatan kepada siswa untuk bekerja 
secara mandiri. Penerapan metode proyek pada pembelajaran IPA mampu memberikan manfaat yang besar untuk memberi pengalaman belajar yang lebih menarik dan berkesan untuk siswa. Hal itu didukung oleh pendapat Wibowo (2008) bahwa pembelajaran IPA di tingkat SD/MI mempunyai tujuan untuk membangun keterampilan siswa dalam proses memecahkan masalah, menyelidiki alam sekitar, dan membuat keputusan. Salah satu materi IPA yang dapat dilakukan dengan metode proyek adalah materi tumbuhan hijau.

Pengalaman belajar diperoleh melalui serangkaian kegiatan dengan menggunakan lingkungan sebagai sumber belajar, baik melalui interaksi aktif dengan teman, lingkungan, maupun narasumber. Pengalaman belajar bersumber dari kebutuhan dan tujuan belajar, sehingga proses belajar dapat berlangsung secara efektif. Belajar merupakan suatu proses atau interaksi yang dilakukan seseorang dalam memperoleh sesuatu yang baru dalam bentuk perubahan perilaku sebagai hasil dari pengalaman itu sendiri (Uno, 2007).

Proses belajar dipengaruhi oleh tiga hal penting, yaitu kondisi eksternal, kondisi internal, dan hasil belajar (Dimyati, 2006). Komponen tersebut harus terpenuhi dengan baik agar dapat menghasilkan hasil belajar yang sesuai dan maksimal. Hasil belajar dapat berupa perubahan perilaku, sikap, keterampilan, serta perolehan nilai tes pada proses pembelajaran.

Menurut Uno (2007), agar proses pembelajaran menjadi bermanfaat, maka kegiatan pembelajaran harus dirancang dengan pendekatan pembelajaran yang mengutamakan kompetensi siswa dalam menyelesaikan masalah, mampu berpikir kreatif, dan inovatif. Untuk mewujudkannya, guru merancang kegiatan belajar kontruktivisme yang dapat dilakukan dengan memodifikasi proses pembelajaran. Berdasarkan hal tersebut guru hendaknya mampu merancang pembelajaran yang mendidik.

Ada beberapa manfaat yang diperoleh dari pembelajaran proyek, diantaranya menurut Moursund (dalam Wena, 2011: 147) pembelajaran berbasis proyek dapat 1) meningkatkan semangat siswa dalam belajar yaitu siswa merasa lebih bergairah dalam pembelajaran, membuat siswa menjadi tekun dan berusaha untuk menyelesaikan proyek. 2) membantu siswa agar lebih mudah dalam menyelesaikan masalah dan membuat siswa menjadi lebih aktif. 3) meningkatkan kemampuan komunikasi antar siswa, kerja kelompok kooperatif, bertukar informasi merupakan aspek kerjasama dari sebuah proyek. 4) memberikan pengalaman dalam mangatur proyek dan pengatur waktu yang dibutuhkan dengan maksimal untuk menyelesaikan tugasnya.

\section{METODE}

Penelitian Tindakan Kelas (PTK) merupakan jenis dari penelitian ini. Penelitian Tindakan Kelas (Classroom Action Research) yaitu penelitian yang dilakukan oleh guru di kelasnya (sekolah) dengan menekankan pada penyempurnaan atau peningkatan proses dan aplikasi pembelajaran (Sa'dun, 2009). Subyek penelitian ini merupakan siswa kelas V di SDN 2 Ngepeh Kecamatan Tugu Kabupaten Trenggalek pada semester genap tahun pelajaran 2018/2019 yang berjumlah 28 siswa yang terdiri dari 15 siswa perempuan dan 13 siswa laki-laki. Penelitian ini dilaksanakan mulai tanggal 1 sampai dengan 13 Maret 2019 pada semester genap tahun pelajaran 2018/2019. Diawali dengan kegiatan perbaikan pembelajaran pada siklus I berdasarkan pengamatan yang dilakukan sebelum penelitian. Hasil pembahasan dari kegiatan refleksi atas penerapan tindakan pada siklus I sebagai hal dasar dalam menentukan langkah-langkah perbaikan tindakan pada siklus berikutnya. Jika pada pelaksanaan siklus I belum terjadi perbaikan terhadap proses pembelajaran dan hasil belajar belum memenuhi Kriteria Ketuntasan Minimal (KKM) yang telah ditetapkan, maka akan dilanjutkan pada siklus II. Hasil akhir pemberian tindakan pada siklus II ini akan menjadi refleksi akhir penelitian. Penelitian ini menerapkan empat tahapan dasar yang saling terkait dan berkesinambungan yaitu perencanaan, pelaksanaan, pengamatan dan refleksi (Sa'dun, 2009). Teknik pengumpulan data menggunakan tes dan 
observasi sedangkan analisis data menggunakan tiga langkah yaitu pengumpulan data, pengolahan data, dan interpretasi data. Data yang dinalisis terdiri dari analisis hasil observasi siswa dalam pelaksanaan pembelajaran dan analisis hasil belajar siswa.

\section{Siklus I}

\section{HASIL DAN PEMBAHASAN}

Pada siklus pertama ini, peneliti merencanakan pembelajaran IPA Kelas V pada materi tumbuhan hijau. Dalam melaksanakan pembelajaran, guru masih menggunakan pembelajaran seperti biasanya, dalam arti secara tradisional yang menerapkan metode ceramah, pemberian tugas, dan tanya jawab. Dalam hal ini, peneliti ingin mengidentifikasi permasalahan yang dihadapi guru dalam pembelajaran tersebut. Di samping itu, peneliti juga ingin mengetahui aktivitas dan hasil belajar siswa pada pembelajaran tersebut.

Metode yang digunakan dalam pembelajaran adalah ceramah, pemberian tugas, dan tanya jawab. Alat pelajaran berupa gambar yang digunakan dalam proses pembelajaran pada materi tumbuhan hijau. Dalam pembelajaran siklus pertama ini, pengenalan materi dilakukan dengan membaca buku materi dan guru menjelaskan tentang materi tersebut. Guru mengamati aktivitasbelajar siswa selama proses pembelajaran siklus I. Dari hasil observasi kerja kelompok diperoleh data sebagai berikut:

Tabel 1. Hasil Nilai Aktivitas Belajar Siswa Siklus I pada Materi Tumbuhan Hijau

\begin{tabular}{|c|c|c|c|c|c|}
\hline \multirow{2}{*}{ No } & \multirow{2}{*}{$\begin{array}{c}\text { Nama } \\
\text { Kelompok }\end{array}$} & \multicolumn{3}{|c|}{ Aspek yang Dinilai } & $\begin{array}{c}\text { Rata-rata } \\
\text { Kelompok }\end{array}$ \\
\cline { 3 - 6 } & Keaktifan & Kerja Sama & Kebenaran & 69 \\
\hline 1. & Kelompok 1 & 70 & 69 & 69 & 66 \\
\hline 2. & Kelompok 2 & 65 & 67 & 66 & 68 \\
\hline 3. & Kelompok 3 & 68 & 69 & 68 & 70 \\
\hline 4. & Kelompok 4 & 71 & 70 & 69 & 66 \\
\hline 5. & Kelompok 5 & 66 & 68 & 65 & \\
\hline & Rata-rata Kelas & 68 & 69 & 67 & \\
\hline
\end{tabular}

Pada akhir proses pembelajaran siklus I ini, siswa diminta mengerjakan soal tes. Dari hasil tes tersebut diperoleh data sebagai berikut:

Tabel 2. Hasil Nilai Tes Siklus I pada Materi Tumbuhan Hijau

\begin{tabular}{|c|c|c|c|}
\hline No & Nomor Subjek & Nilai & Keterangan \\
\hline 1 & SI1 & 50 & TT \\
\hline 2 & SI2 & 65 & TT \\
\hline 3 & SI3 & 65 & TT \\
\hline 4 & SI4 & 70 & T \\
\hline 5 & SI5 & 60 & TT \\
\hline 6 & SI6 & 65 & TT \\
\hline 7 & SI7 & 70 & T \\
\hline 8 & SI8 & 50 & TT \\
\hline 9 & SI9 & 70 & T \\
\hline 10 & SI10 & 80 & TT \\
\hline 11 & SI11 & 65 & TT \\
\hline 12 & SI12 & 60 & T \\
\hline 13 & SI13 & 70 & TT \\
\hline 14 & SI14 & 60 & TT \\
\hline 15 & SI15 & 60 & T \\
\hline 16 & SI16 & 70 & TT \\
\hline 17 & SI17 & 70 & SI18 \\
\hline 18 & SI & 60 & \\
\hline
\end{tabular}




\begin{tabular}{|c|c|c|c|}
\hline 19 & SI19 & 50 & TT \\
\hline 20 & SI20 & 90 & $\mathrm{~T}$ \\
\hline 21 & SI21 & 60 & $\mathrm{TT}$ \\
\hline 22 & $\mathrm{SI} 2$ & 90 & $\mathrm{~T}$ \\
\hline 23 & $\mathrm{SI} 23$ & 90 & $\mathrm{~T}$ \\
\hline 24 & $\mathrm{SI} 24$ & 90 & $\mathrm{~T}$ \\
\hline 25 & $\mathrm{SI} 25$ & 65 & $\mathrm{TT}$ \\
\hline 26 & $\mathrm{SI} 26$ & 50 & $\mathrm{TT}$ \\
\hline 27 & $\mathrm{SI} 27$ & 60 & $\mathrm{TT}$ \\
\hline 28 & SI28 & 70 & $\mathrm{~T}$ \\
\hline & $\begin{array}{c}\text { Nilai Rata-rata } \\
\text { Kelas }\end{array}$ & $\mathbf{6 6 , 9}$ & $\begin{array}{c}\text { T=Tuntas } \\
\text { TT=Tidak Tuntas }\end{array}$ \\
\hline
\end{tabular}

Berdasarkan tabel 1 tentang aktivitas belajar siswa siklus I pada materi tumbuhan hijau di atas dapat dianalisa bahwa dari 5 kelompok yang menjadi subyek penelitian diperoleh rata-rata kelas pada aspek keaktifan sebesar 68, aspek kerja sama sebesar 69, dan aspek kebenaran sebesar 67. Dari ketiga aspek tersebut diperoleh rata-rata aktivitas siswa yang kurang dari 70, sehingga dapat disimpulkan bahwa aktivitas belajar siswa masih kurang aktif dan siswa kurang termotivasi pada proses pembelajaran.

Berdasarkan tabel 2 di atas dapat dianalisa bahwa dari 28 siswa yang menjadi subyek penelitian yang belum mencapai standart ketuntasan minimal (SKM) mata pelajaran IPA di SDN 2 Ngepeh adalah 16 siswa (57\%), sedangkan yang telah tuntas atau memenuhi nilai SKM mata pelajaran IPA adalah 12 siswa (43\%). Dengan demikian dapat dikatakan bahwa prosentase siswa yang belum mencapai kriteria ketuntasan minimal (KKM) mata pelajaran IPA di SDN 2 Ngepeh adalah 53\%, berarti tingkat keberhasilan siswa dalam pembelajaran ini kurang dari $70 \%$ dan diperoleh nilai rata-rata kelas 66,9 sehingga dapat disimpulkan tingkat keberhasilan prestasi belajar siswa kelas $\mathrm{V}$ SDN $2 \mathrm{Ngepeh}$ dalam menjawab pertanyaan dan memahami materi tumbuhan hijau belum berhasil, untuk itu perlu dilakukan pembelajaran berikutnya.

Ada dua hal penting yang dapat direfleksikan dari hasil penelitian siklus pertama ini yaitu: (1) pembelajaran perlu ditingkatkan karenaaktivitas siswa masih kurang aktif dan hasil belajar siswa belum memenuhi kriteria ketuntasan minimal (KKM) mata pelajaran IPA di SDN 2 Ngepeh yaitu 70, (2) penggunaan model dan media pembelajaran terutama pada materi tumbuhan hijau perlu diperbaiki karena siswa belum mampu menyelesaikan soal. Selanjutnya, kedua hal tersebut akan menjadi fokus masalah pada penelitian pembelajaran siklus kedua.

\section{Siklus II}

Pada siklus kedua ini, dengan memperhatikan permasalahan yang terjadi pada siklus pertama. Target yang diharapkan tercapai pada siklus ini adalah (1) keberhasilan dalam proses pembelajaran, (2) keefektifan, efisensi, dan kemenarikan metode proyek pada proses pembelajaran.

Pada siklus ini, guru merencanakan pembelajaran yang sesuai dengan langkah-langkah pada rencana pembelajaran yang telah disusun. Dalam pelaksanaan pembelajaran siklus II ini, guru menggunakan metode proyek yaitu siswa dibagi menjadi beberapa kelompok untuk membuktikan bahwa proses fotosintesis memerlukan cahaya matahari. Setiap kelompok terdiri dari 5-6 siswa yang heterogen berdasarkan jenis kelamin dan kemampuan akademiknya. Pada kegiatan percobaan tersebut, setiap kelompok diminta untuk menentukan alat dan bahan yang dibutuhkan, serta langkah kerja terlebih dahulu, kemudian setiap kelompok melakukan percobaan sendiri sesuai dengan petunjuk percobaan yang telah ditentukan.

Setelah kegiatan percobaan selesai, masing-masing kelompok mendiskusikan hasil pengamatan dan setiap kelompok diminta mempresentasikan tentang kegiatan percobaan yang telah dilakukan. Pada tahap ini,proses pembelajaran diorientasikan pada kegiatan siswa aktif dan antusias dalam melakukan kegiatan 
percobaanmembuktikan proses fotosintesis memerlukan cahaya matahari. Hal ini menunjukkan tingkat keefektifan dalam penggunaan metode pembelajaran proyek sudah kelihatan.Dari hasil observasi kerja kelompok tentang aktivitas siswa diperoleh data sebagai berikut:

Tabel 3. Hasil Nilai Aktivitas Belajar Siswa Siklus Il pada Materi Tumbuhan Hijau

\begin{tabular}{|c|l|c|c|c|c|}
\hline \multirow{2}{*}{ No } & \multirow{2}{*}{$\begin{array}{c}\text { Nama } \\
\text { Kelompok }\end{array}$} & \multicolumn{3}{|c|}{ Aspek yang Dinilai } & $\begin{array}{c}\text { Rata-rata } \\
\text { Kelompok }\end{array}$ \\
\cline { 3 - 6 } & Keaktifan & Kerja Sama & Kebenaran & 75 \\
\hline 1. & Kelompok 1 & 76 & 75 & 76 & 74 \\
\hline 2. & Kelompok 2 & 74 & 74 & 75 & 75 \\
\hline 3. & Kelompok 3 & 76 & 75 & 75 & 78 \\
\hline 4. & Kelompok 4 & 80 & 77 & 78 & 76 \\
\hline 5. & Kelompok 5 & 77 & 76 & 75 & \\
\hline & Rata-rata Kelas & 77 & 75 & 76 & \\
\hline
\end{tabular}

Pada akhir proses pembelajaran siklus II ini, siswa juga diminta mengerjakan soal tes untuk mengetahui hasil belajar pada pembelajaran dengan menerapkan metode proyek. Dari hasil tes tersebut diperoleh data sebagai berikut:

Tabel 4. Distribusi Nilai Tes Siklus II pada Materi Tumbuhan Hijau

\begin{tabular}{|c|c|c|c|}
\hline No & Nomor Subjek & Nilai & Keterangan \\
\hline 1 & SI1 & 60 & TT \\
\hline 2 & $\mathrm{SI} 2$ & 75 & $\mathrm{~T}$ \\
\hline 3 & $\mathrm{SI} 3$ & 75 & $T$ \\
\hline 4 & $\mathrm{SI} 4$ & 80 & $T$ \\
\hline 5 & SI5 & 70 & $T$ \\
\hline 6 & SI6 & 75 & $T$ \\
\hline 7 & SI7 & 80 & $T$ \\
\hline 8 & SI8 & 60 & TT \\
\hline 9 & SI9 & 85 & $\mathrm{~T}$ \\
\hline 10 & SI10 & 90 & $T$ \\
\hline 11 & Sl11 & 70 & $\mathrm{~T}$ \\
\hline 12 & SI12 & 75 & $T$ \\
\hline 13 & SI13 & 85 & $\mathrm{~T}$ \\
\hline 14 & SI14 & 70 & $T$ \\
\hline 15 & Sl15 & 70 & $\mathrm{~T}$ \\
\hline 16 & SI16 & 85 & $T$ \\
\hline 17 & SI17 & 80 & $T$ \\
\hline 18 & SI18 & 75 & $T$ \\
\hline 19 & SI19 & 60 & TT \\
\hline 20 & SI20 & 100 & $T$ \\
\hline 21 & SI21 & 75 & $T$ \\
\hline 22 & SI22 & 95 & $\mathrm{~T}$ \\
\hline 23 & SI23 & 100 & $T$ \\
\hline 24 & SI24 & 100 & $\mathrm{~T}$ \\
\hline 25 & SI25 & 75 & $T$ \\
\hline 26 & SI26 & 65 & TT \\
\hline 27 & SI27 & 75 & $\mathrm{~T}$ \\
\hline 28 & SI28 & 85 & $T$ \\
\hline & $\begin{array}{c}\text { Nilai Rata-rata } \\
\text { Kelas }\end{array}$ & 78,4 & \\
\hline
\end{tabular}

Berdasarkan tabel 3. tentang aktivitas belajar siswa siklus II pada materi tumbuhan hijau di atas dapat dianalisa bahwa dari 5 kelompok yang menjadi subyek penelitian diperoleh rata-rata kelas pada aspek keaktifan sebesar 77 , aspek kerja 
sama sebesar 75 , dan aspek kebenaran sebesar 76 . Dari ketiga aspek tersebut diperoleh rata-rata aktivitas siswa yang lebih dari 70, sehingga dapat disimpulkan bahwa aktivitas belajar siswa mengalami peningkatan aktivitas belajarnya, siswa lebih termotivasi belajar dan aktif dalam proses pembelajaran. Siswa juga dapat bekerja sama dengan kelompoknya.

Berdasarkan tabel 4. dapat dideskripisikan hasil belajar yang diperoleh dari penerapan metode proyek pada materi tumbuhan hijau adalahdari 28 siswa yang menjadi subyek penelitian yang belum mencapai kriteria ketuntasan minimal (KKM) mata pelajaran IPA di SDN 2 Ngepehadalah 4 siswa (15\%), sedangkan yang telah tuntas atau memenuhi nilai KKM mata pelajaran IPA adalah 24 siswa (85\%).

Dengan demikian dapat dikatakan bahwa prosentase siswa yang tuntas atau memenuhi nilai KKM mata pelajaran IPA adalah 85\%, berarti tingkat keberhasilan siswa dalam pembelajaran ini lebih dari $70 \%$ dalam menjawab pertanyaan dan memahami materi tumbuhan hijau telah berhasil. Hal ini menunjukkan bahwa pembelajaran IPAyang menggunakan metode proyek pada materi tumbuhan hijau siswa telah memotivasi dan meningkatkan aktivitas belajar. Dalam siklus ini siswa sebagai pusat pembelajaran, sehingga tercipta proses pembelajaran bermakna dan aktif, serta kreatif.

\section{PEMBAHASAN}

Menurut Hung dan Wong (dalam Wena, 2011), pembelajaran berbasis proyek juga didukung oleh teori aktivitas. Dalam penerapannya di kelas bertumpu pada kegiatan belajar aktif dalam bentuk melakukan sesuatu (doing)daripada kegiatan pasif menerima transfer pengetahuan dari guru. Sesuai dengan teori aktivitas belajar siswa dan berdasarkan analisa data hasil penelitian dapat disimpulkan bahwa secara umum pembelajaran yang menggunakan metode proyek menunjukkan peningkatan aktivitas belajar siswa. Hal ini terlihat dari ketiga aspek yang diamati tentang aktivitas belajar siswa yaitu aspek keaktifan, aspek kerja sama, dan aspek kebenaran. Pada aspek keaktifan dapat diketahui dari siswa aktif berdiskusi, bertanya, dan mengemukakan pendapat dalam kegiatan diskusi. Setiap anggota kelompok juga terlibat aktif dalam kegiatan percobaan membuktikan bahwa proses fotosintesis memerlukan cahaya matahari.

Menurut Vygostsky (dalam Wena, 2011), pembelajaran berbasis proyek dapat dilakukan dengan model belajar kolaboratif dalam kelompok kecil siswa. Sejalan dengan teori konstruktivisme sosial Vygostsky bahwa pembelajaran berbasis proyek dapat membantu siswa meningkatkan keterampilan dan memecahkan masalah secara kolaboratif. Hal ini sesuai dengan aktivitas belajar siswa pada aspek kerja sama yang dapat diketahui bahwa siswa mampu berkomunikasi dengan siswa lainnya, berdiskusi, dan mampu berkerja sama merancang dan melakukan kegiatan percobaan secara mandiri dengan anggota kelompoknya.

Pembelajaran berbasis proyek juga didukung oleh teori belajar konstruktivistik, yang bersandar pada ide bahwa siswa membangun pengetahuannya sendiri di dalam konteks pengalamannya sendiri (Murphy dalam Wena, 2011). Sesuai dengan pendapat tersebut, aktivitas belajar siswa pada aspek kebenaran mengalami peningkatan dari siklus sebelumnya. Siswa dapat menjawab pertanyaan pada lembar kerja kelompok dengan benar dan melakukan kegiatan percobaan dengan runtut dan benar.

Pembelajaran dengan menerapkan metode proyek merupakan salah satu metode yang dapat mendorong siswa membangun pengetahuan dan keterampilannya sendiri dengan bimbingan guru. Siswa dituntut untuk mengamati, membaca, dan meneliti (Aqib, 2013). Hal ini sejalan dengan observasi dan penelitian yang telah dilakukan bahwa metode proyek dapat meningkatkan prestasi belajar siswa.

Peningkatan prestasi belajar siswa pada materi tumbuhan hijau dapat diketahui dari hasil tes diperoleh rata-rata kelas siklus I sebesar 66,9 meningkat menjadi 78,4 pada rata-rata kelas siklus II. Hal ini dikarenakan penerapan metode proyek dapat 
meningkatkan motivasi dan kreatifitas siswa, sehingga siswa akan memperoleh pengalaman dan hasil belajar yang maksimal.

Motivasi belajar sangat penting untuk menentukan sejauh mana siswa belajar dari suatu kegiatan pembelajaran atau seberapa jauh penyerapan informasi yang disajikan kepada mereka (Nur, 1999). Siswa yang tertarik dengan proses pembelajaran yang diterapkan mengakibatkan motivasi untuk belajar meningkat, sehingga pada akhirnya siswa dapat memahami materi dan diperoleh hasil belajar yang memuaskan. Motivasi belajar siswa pada penerapan metode proyek dapat diketahui aktivitas siswa saat proses pembelajaran, diantaranya siswa terlihat lebih bergairah dalam pembelajaran, siswa sangat tekun, dapat bekerja sama dengan kelompoknya, dan berusaha untuk menyelesaikan proyek dengan baik. Dengan demikian, dapat disimpulkan penerapan metode proyekpada pembelajaran IPA lebih memberikan dorongan terhadap pencapaian prestasi belajar dan pemahaman siswa terhadap lingkungan sekitar da menciptakan pembelajaran yang bermakna bagi siswa.

\section{KESIMPULAN}

Berdasarkan hasil penelitian dan analisis data dapat disimpulkan, bahwa: 1) Penerapan metode pembelajaran proyek dapat meningkatkan aktivitas belajar siswa. Hal ini dapat diketahui dari peningkatan aktivitas belajar siswa yaitu diperoleh rata-rata kelas siklus II pada aspek keaktifan sebesar 77, aspek kerja sama sebesar 75 , dan aspek kebenaran sebesar 76. 2) Penerapan metode pembelajaran proyek dapat meningkatkan pemahaman dan hasil belajar siswa. Hal ini dapat diketahui dari hasil tes siklus I bahwa dari 28 siswa yang menjadi subyek penelitian yang mendapat nilai tes kurang dari KKM sebanyak 16 siswa (57\%), sedangkan yang telah tuntas atau memenuhi nilai KKM mata pelajaran IPA adalah 12 siswa (43\%). Hasil tes pada siklus II diketahui sebagian besar subyek penelitian mendapat nilai tes akhir lebih dari KKM sebanyak 24 siswa (85\%), tetapi ada beberapa siswa yang mendapat nilai tes akhir yang sama dengan KKM adalah 4 siswa (15\%). Berdasarkan simpulan di atas, dapat dikemukakan saran sebagai berikut: 1) Sebaiknya proses pembelajaran, khususnya pembelajaranIPA dilakukan dengan menerapkan model proyek pada materilainnya. 2) Pada penerapan metode pembelajaran proyek, sebaiknya guru memperhatikan alokasi waktu dan persiapan pembelajaran agar proses pembelajaran dapat berjalan lebih efektif dan efisien.

\section{DAFTAR PUSTAKA}

Akbar, Sa'dun. 2009. Penelitian Tindakan Kelas. Yogyakarta: Cipta Media Aksara. Arikunto, Suharsimi. 2006. Prosedur Penelitian Suatu Pendekatan Praktik. Jakarta: Rineka Cipta.

Aqib, Zainal. 2013. Model-model, Media, dan Strategi Pembelajaran Kontekstual (Inovatif). Bandung: Yrama Widya

Dimyati dan Mudjiono. 2006. Belajar dan Pembelajaran. Jakarta: Rineka Cipta Hamalik, Oemar. 2007. Proses Belajar Mengajar. Jakarta: Bumi Aksara Haryanto. 2007. Sains Jilid 5 untuk Sekolah Dasar Kelas V. Jakarta: Erlangga Nur, M. 1999. Teori Belajar. Surabaya: UNESA University Press.

Rositawaty dan Aris Muharam. 2008. Senang Belajar Ilmu Pengetahuan Alam untuk Kelas V SD/MI. Jakarta: Pusat Perbukuan.

Sudjana, Nana. 2005. Penilaian Hasil Proses Belajar Mengajar. Bandung: Remaja Rosda Karya

Surya, Yohannes. 2006. IPA dibuat asyik untuk Sekolah Dasar Kelas 5A. Armandelta Selaras

Uno, B. Hamzah. 2007. Teori Motivasi dan Pengukurannya. Jakarta: Bumi Aksara

Wena, Made. 2011. Strategi Pembelajaran Inovatif Kontemporer. Jakarta: Bumi Aksara Wibowo, Eddy Mungin. 2008. Pedomen Penyususnan KTSP SD. Jakarta: DEPDIKNAS 